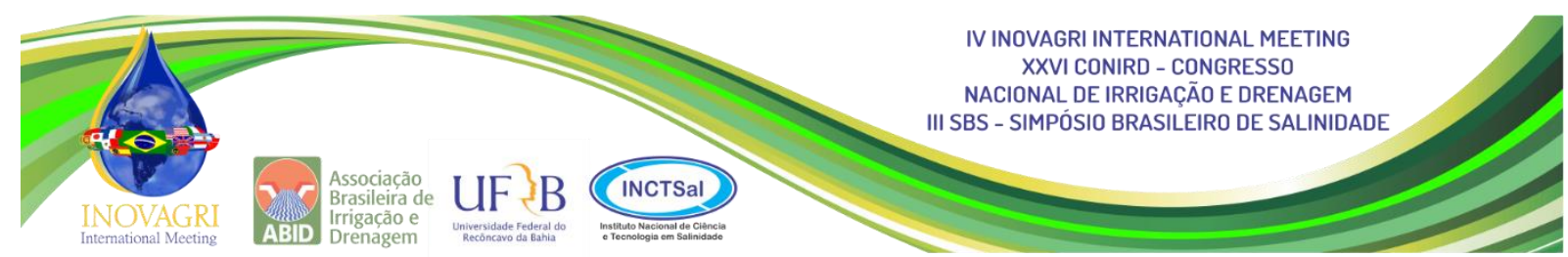

\title{
MELON PRDUTIVITY UNDER DIFFERENT SOIL COVERINGS AND IRRIGATION SYSTEM IN PETROLINA - PE
}

\author{
C. E. F. Possidio' ${ }^{1}$, A. D. A. de Almeida ${ }^{2}$, J. S. C. de Sousa ${ }^{3}$, W. L. Simões ${ }^{4}$
}

\begin{abstract}
The objective of this work was to evaluate the influence of irrigation system and soil cover on yield of yellow melon in Petrolina / PE. The experiment was carried out in the period from April 09, 2016 to June 8, 2016 and was conducted at the Petrolina campus in the IF Sertão - PE rural area, with a randomized complete block design, 2 x 2 x 3 plot scheme, (One and two lines of drippers per row of plants), and the subsubparcels, three soil cover (black mulching cover), two plots of hybrids (Gladial and 10/00), subplots, two irrigation systems, Cover with mulching grey and without soil cover) and six replicates. Mulching efficiency (MPP) was studied in the soil cover and irrigation system located with drippers for the production of yellow hybrid melon 10/00 and Gladial under field conditions. It was verified the statistical influence of the soil cover on melon productivity.
\end{abstract}

KEYWORDS: Mulching, gladial, influence

\section{PRDUTIVIDADE DE MELÃO SOB DIFERENTES COBETURAS DE SOLO E SISTEMA DE IRRIGAÇÃO EM PETROLINA - PE}

RESUMO: O objetivo deste trabalho foi avaliar a influência do sistema de irrigação e da cobertura do solo na produtividade de melão amarelo em Petrolina/PE. O experimento foi realizado no período de 09 de Abril de 2016 à 08 de Junho de 2016 e conduzido no campus Petrolina Zona Rural do IF Sertão - PE, com delineamento experimental em blocos casualizados, esquema de parcelas subsubdivididas, $2 \times 2 \times 3$, sendo as parcelas, dois híbridos de melão - ( Gladial e 10/00), as subparcelas, dois sistemas de irrigação - ( uma e duas linhas de gotejadores por fileira de plantas), e as subsubparcelas, três coberturas de solo (cobertura com mulching preto, cobertura com mulching cinza e sem cobertura de solo) e seis repetições. Estudou-se a eficiência de Mulching (MPP) na cobertura de solo e sistema de irrigação localizado com gotejadores para produção de melão híbrido amarelo 10/00 e Gladial em

\footnotetext{
${ }^{1}$ Acadêmico de Agronomia, IF Sertão-PE, campus zona rural, Petrolina-Pernambuco. Email: agropossidio@gmail.com.

${ }^{2}$ Tecnóloga em Viticultura e Enologia, IF Sertão-PE, Petrolina-Pernambuco.

${ }^{3}$ Doutor, professor do IF Sertão-PE, Petrolina-Pernambuco.

${ }^{4}$ Doutor, pesquisador EMBRAPA Semiárido, Petrolina-Pernambuco.
} 
condições de campo. Constatou-se influência estatística da cobertura do solo na produtividade do melão.

PALAVRAS-CHAVES: Mulching, gladial, influência

\section{INTRODUCTION}

The Northeast Region stands out in the production of melon from Rio Grande do Norte, Ceará, Bahia and Pernambuco, with the main types being Sap, Yellow, Gaul and Cantaloupe, Lima et al. (2015). Some yellow hybrids have been preferred because of their higher yields, but there are no conclusive reports of how much more is produced. The spacing practiced with 0.30 to $0.50 \mathrm{~m}$ between plants and $2.00 \mathrm{~m}$ between rows of plants, Cavalcanti et al. (2008).

The São Francisco Valley is a pole of Brazilian fruit and vegetable growing in this semiarid region of the country, as high productivity and quality, is mainly due to favorable climatic conditions and edaphic conditions of the region (LEMOS et al., 2012; EMBRAPA, 2016).

Batista et al. (2009), says that for the success of melon cultivation a choice of a good variety is necessary, along with efficient irrigation and cultural treatments such as fertilization, crop management, pest and disease control, soil coverings, etc.

Abreu et al. (1978) quoted Shmueli \& Goldberg (1971), who investigated melon cultivation under furrow irrigation, sprinkling and drip irrigation, observed greater yield with drip and significant crop novelty for irrigation and sprinkler systems.

Vermeiren \& Jobling, 1997; Gomes, 1999; Bernardo et al., 2006 recommend a percentage of wet soil of $33 \%$ for semi-arid regions. The spacing practiced in melon cultures, with the use of a single row of drippers promoted wet bulb diameter around 0.50 m, Mantovani et al. (2009), which generates smaller wet soil percentages than is recommended in the literature.

The use of the plastic cover of the soil for the cultivation of melon is a practice that has been widely diffused in the region of the São Francisco Valley.

Câmara Monteiro (2007) says in his study that using coverage coverage increased productivity. This increase can also be observed in the work of Medeiros et al. (2006), where productivity reached $39 \%$ higher than crops without plastic cover.

The color of the mulching is another factor that influences the melon production observed by Gondim et al. (2009) to the growth and physiological growth index, in Cantaloupe melon hybrids submitted to cultivation in open soil and covered with polyethylene films of different cores, in Mossoró / RN. 
However, the objective of this work was to evaluate the influence of two irrigation systems and three types of soil cover on yield of two hybrids of Yellow melon in Petrolina / PE

\section{MATERIALS AND METHODS}

This work was carried out at the Federal Institute of Sertão Pernambucano, Petrolina rural campus, located at Rodovia BR 235, Km 22 - Project Senador Nilo Coelho - N4 Petrolina / PE, latitude $9^{\circ} 20$ ' 14.14 "S, longitude $40^{\circ} 42^{\prime} 01.27$ "W; And altitude of 418 meters in the period from April 9, 2016 to June 8, 2016. According to the classification of Köppen the region shows BSwh 'climate, corresponding to a warm, semi-arid, steppe-like climate with rainy summer, Evapotranspiration, with the temperature of the coldest month being above $18^{\circ} \mathrm{C}$ (Oliveira, 2010). The soil was classified as Yellow Argissolo with a sandy loam texture.

The experimental design was completely randomized blocks, adding six blocks with a scheme of sub-divided plots, $2 \times 2 \times 3$, the plots being; Two hybrids of melon, where H1 (Gladial) and H2 (10/00), the subplots; Two irrigation systems, where S1 (one line of drippers per row of plants) and S2 (two lines of drippers per row of plants), the subsubparcels; Three soil coverages, C1 (black mulch cover), C2 (gray mulch cover) and C3 (uncovered), with subsubparcels of six plants (repetitions) as shown in Figure 1. The spacing of $0.3 \mathrm{~m} \times 2.0 \mathrm{~m}$, forming a useful area of $0.6 \mathrm{~m}^{2}$ per plant.

\begin{tabular}{|c|c|c|c|c|c|c|c|c|}
\hline \multicolumn{3}{|c|}{ Bloco 1} & \multicolumn{3}{|c|}{ Bloco 2} & \multicolumn{3}{|c|}{ Bloco 3} \\
\hline $\mathrm{H} 2 \mathrm{~S} 2 \mathrm{C} 1$ & $\mathrm{H} 2 \mathrm{~S} 2 \mathrm{C} 2$ & $\mathrm{H} 2 \mathrm{~S} 2 \mathrm{C} 3$ & $\mathrm{H} 1 \mathrm{~S} 1 \mathrm{C} 1$ & $\mathrm{H} 1 \mathrm{~S} 1 \mathrm{C} 3$ & $\mathrm{H} 1 \mathrm{~S} 1 \mathrm{C} 2$ & $\mathrm{H} 2 \mathrm{~S} 1 \mathrm{C} 3$ & $\mathrm{H} 2 \mathrm{~S} 1 \mathrm{C} 1$ & $\mathrm{H} 2 \mathrm{~S} 1 \mathrm{C} 2$ \\
\hline $\mathrm{H} 2 \mathrm{~S} 1 \mathrm{C} 1$ & $\mathrm{H} 2 \mathrm{~S} 1 \mathrm{C} 3$ & $\mathrm{H} 2 \mathrm{~S} 1 \mathrm{C} 2$ & $\mathrm{H} 1 \mathrm{~S} 2 \mathrm{C} 3$ & $\mathrm{H} 1 \mathrm{~S} 2 \mathrm{C} 2$ & $\mathrm{H} 1 \mathrm{~S} 2 \mathrm{C} 1$ & $\mathrm{H} 2 \mathrm{~S} 2 \mathrm{C} 3$ & $\mathrm{H} 2 \mathrm{~S} 2 \mathrm{C} 2$ & $\mathrm{H} 2 \mathrm{~S} 2 \mathrm{C} 1$ \\
\hline $\mathrm{H} 1 \mathrm{~S} 2 \mathrm{C} 3$ & $\mathrm{H} 1 \mathrm{~S} 2 \mathrm{C} 1$ & $\mathrm{H} 1 \mathrm{~S} 2 \mathrm{C} 2$ & $\mathrm{H} 2 \mathrm{~S} 2 \mathrm{C} 2$ & $\mathrm{H} 2 \mathrm{~S} 2 \mathrm{C} 1$ & $\mathrm{H} 2 \mathrm{~S} 2 \mathrm{C} 3$ & $\mathrm{H} 1 \mathrm{~S} 1 \mathrm{C} 2$ & $\mathrm{H} 1 \mathrm{~S} 1 \mathrm{C} 1$ & $\mathrm{H} 1 \mathrm{~S} 1 \mathrm{C} 3$ \\
\hline $\mathrm{H} 1 \mathrm{~S} 1 \mathrm{C} 2$ & $\mathrm{H} 1 \mathrm{~S} 1 \mathrm{C} 1$ & $\mathrm{H} 1 \mathrm{~S} 1 \mathrm{C} 3$ & $\mathrm{H} 2 \mathrm{~S} 1 \mathrm{C} 3$ & $\mathrm{H} 2 \mathrm{~S} 1 \mathrm{C} 2$ & $\mathrm{H} 2 \mathrm{~S} 1 \mathrm{C} 1$ & $\mathrm{H} 1 \mathrm{~S} 2 \mathrm{C} 2$ & $\mathrm{H} 1 \mathrm{~S} 2 \mathrm{C} 3$ & $\mathrm{H} 1 \mathrm{~S} 2 \mathrm{C} 1$ \\
\hline \multicolumn{3}{|c|}{ Bloco 4} & \multicolumn{3}{|c|}{ Bloco 5} & \multicolumn{3}{|c|}{ Bloco 6} \\
\hline $\mathrm{H} 1 \mathrm{~S} 1 \mathrm{C} 1$ & $\mathrm{H} 1 \mathrm{~S} 1 \mathrm{C} 2$ & $\mathrm{H} 1 \mathrm{~S} 1 \mathrm{C} 3$ & $\mathrm{H} 1 \mathrm{~S} 2 \mathrm{C} 1$ & $\mathrm{H} 1 \mathrm{~S} 2 \mathrm{C} 3$ & $\mathrm{H} 1 \mathrm{~S} 2 \mathrm{C} 2$ & $\mathrm{H} 2 \mathrm{~S} 2 \mathrm{C} 3$ & $\mathrm{H} 2 \mathrm{~S} 2 \mathrm{C} 1$ & $\mathrm{H} 2 \mathrm{~S} 2 \mathrm{C} 2$ \\
\hline $\mathrm{H} 1 \mathrm{~S} 2 \mathrm{C} 3$ & $\mathrm{H} 1 \mathrm{~S} 2 \mathrm{C} 1$ & $\mathrm{H} 1 \mathrm{~S} 2 \mathrm{C} 2$ & $\mathrm{H} 1 \mathrm{~S} 1 \mathrm{C} 2$ & $\mathrm{HIS} 1 \mathrm{C} 1$ & $\mathrm{H} 1 \mathrm{~S} 1 \mathrm{C} 3$ & $\mathrm{H} 2 \mathrm{~S} 1 \mathrm{C} 2$ & $\mathrm{H} 2 \mathrm{~S} 1 \mathrm{C} 3$ & $\mathrm{H} 2 \mathrm{~S} 1 \mathrm{C} 1$ \\
\hline $\mathrm{H} 2 \mathrm{~S} 2 \mathrm{C} 3$ & $\mathrm{H} 2 \mathrm{~S} 2 \mathrm{C} 1$ & $\mathrm{H} 2 \mathrm{~S} 2 \mathrm{C} 2$ & $\mathrm{H} 2 \mathrm{~S} 1 \mathrm{C} 1$ & $\mathrm{H} 2 \mathrm{~S} 1 \mathrm{C} 3$ & $\mathrm{H} 2 \mathrm{~S} 1 \mathrm{C} 2$ & $\mathrm{H} 1 \mathrm{~S} 1 \mathrm{C} 3$ & $\mathrm{H} 1 \mathrm{~S} 1 \mathrm{C} 1$ & $\mathrm{H} 1 \mathrm{~S} 1 \mathrm{C} 2$ \\
\hline $\mathrm{H} 2 \mathrm{~S} 1 \mathrm{C} 1$ & $\mathrm{H} 2 \mathrm{~S} 1 \mathrm{C} 3$ & $\mathrm{H} 2 \mathrm{~S} 1 \mathrm{C} 2$ & $\mathrm{H}_{2} \mathrm{~S}_{2} \mathrm{C}_{3}$ & $\mathrm{H} 2 \mathrm{~S}_{2} \mathrm{C}_{2}$ & $\mathrm{H} 2 \mathrm{~S} 2 \mathrm{C} 1$ & $\mathrm{H} 1 \mathrm{~S} 2 \mathrm{C} 2$ & $\mathrm{H} 1 \mathrm{~S}_{2} \mathrm{C}_{3}$ & $\mathrm{H} 1 \mathrm{~S}_{2} \mathrm{C} 1$ \\
\hline
\end{tabular}

Figure 1. Arrangement of treatments in the experimental area. Where: H1 - gladial melon; H2 - melon 10/00; S1 - one row of drippers per row of plants; S2 - two rows of drippers per row of plants; C1 - soil covered with black mulching; C2 - soil covered with gray mulching; $\mathrm{C} 3$ - soil without cover.

The preparation of the area consisted of subsoiling, plowing and harrowing, after which the surveys were carried out. The beds were made with $1.0 \mathrm{~m}$ wide and $0.2 \mathrm{~m}$ high. This was followed by the installation of irrigation systems and soil cover. Seeding was carried out in 
polyethylene trays, where each cell was seeded with a seed and kept in a hydroponic nursery until transplanted to the growing area after 12 days.

Before the transplanting of the seedlings to the experimental area, the soil was collected and analyzed. Planting fertilization consisted of MAP (40 kg/ha-1 of P2O5) and nitrogen and potassium fertilization were carried out in the plantation and in urea cover ( $120 \mathrm{~kg} / \mathrm{ha}-1$ of $\mathrm{N})$ and potassium sulphate (40 kg/ha-1 of $\mathrm{K} 2 \mathrm{O}$ ), and all fertilizer application was performed by fertigation and divided into 12 plots during the cycle, based on the phenological phases of the crop. Cultural treatments and phytosanitary control were those commonly employed in crop repairs.

According to the methodology of Bernardo et al. (2009) and Mantovani et al. (2009) evaluated the irrigation system, uniformity of water distribution and pressure tests before and after the productive cycle.

For the irrigation management, an irrigation worksheet was used from the sequential water balance of the crop, fed with daily data from the Petrolina Zona Rural automatic weather station, Devis brand and model VantagePro2. The cultural coefficient (kc) used was presented by FAO (Allen et al., 1998) and Vermeiren \& Jobling's methodology (1997). Irrigations were carried out in the afternoon every day, beginning on April 9 and ending on June 5, three days before harvest.

The harvest was performed on June 8, 2016 in the morning. All steaks of similar color and size were obtained by sub-subplots and quantified total fruit number (NFT), commercial fruit number (NFC), non-commercial fruit number (NFNC), total weight (PT), commercial weight And noncommercial weight (PNC). With the spacing of the useful area per plant one can estimate productivity of each treatment used.

The data were submitted to analysis of variance and the means were compared by the Tukey test at $5 \%$ of probability.

\section{RESULTS AND DISCUSSIONS}

According to (SIDRA, 2015), an average melon production without Brazil was 25,123 kg / ha, while an average for the Northeast region was $27,412 \mathrm{~kg} /$ ha. Regarding the study, the lowest average productivity was observed without C3 coverage of $33,912 \mathrm{~kg} / \mathrm{ha}$, and the highest also for C2 coverage coverage of 43,518 kg / ha. As estimated means for total productivity analyzed, they show a statistical difference between treatment C2 (gray mulching) and C3 (uncovered) treatment evidenced in Table 1. 
According to the data analyzed, a statistical difference was observed for the treatment with soil cover in relation to the uncovered, in the commercial fruit yield media, where mulching treatment with gray and black mulching obtained higher yields than without cover (Table 2).

A soil cover provided higher productivity, which agrees with Medeiros et al. (2006), when analyzing the growth and production of cultivated melon under soil cover and different irrigation frequencies, Câmara Monteiro (2007), in his study "Productive and quality aspects of melon under underground drip and" plastic mulching "that The use of the plastic cover increased the crop productivity of meloeiro e Silva et al. (2005), when studying the production of melon fruits under different levels of irrigation water salinity, with and without soil cover. Brandenberger and Wiendenfeld (1997) also found an increase in melon production with the use of soil cover in relation to the uncovered soil.

The increase in temperature associated with the maintenance of soil moisture promoted by the coverage factor of our treatments $\mathrm{C} 1$ and $\mathrm{C} 2$ should be influenced by a greater availability of nutrients for the plants, increasing the productivity compared to the treatment without cover, C3. According to Zapata et al. (1989) and Sampaio et al. (1999), there is an increased availability of nutrients in the soil when microbial activity is accelerated, promoting greater mineralization of organic nitrogen and nitrification of fertilizers as the temperature and soil moisture are increased in the more superficial layers of the soil, in addition to reducing as losses by leaching and volatilization of essential nutrients for the plants.

The data in Table 3 shows that there was no significant statistical variation for the mean number of fruits in any of the factors studied. Thus, as the observations in table 2 for the soil cover factor is proved of a greater increase in the average weight of the fruits.

It was observed with the data studied that they did not have the statistical difference in the interaction of the experienced factors, lacking variable collected, as shown in tables 2, 3 and 4.

\section{CONCLUSION}

The irrigation system with two rows of drippers not interfering in productivity for hybrids of yellow melon "10-00" and "Gladial".

For commercial productivity, the referent study shows the use of non-soil cover (plastic mulching) promotes a statistically significant increase in relation to the productivity of melon without soil cover. 
C. E. F. Possidio et al.

The use of gray plastic mulching had a higher productivity index compared to black mulching, even though it did not differ statistically from one another.

Table 1. Average yield of total melon yield ( $\mathrm{kg} / \mathrm{ha}$ ) submitted to two hybrids, two irrigation systems and three soil coverages. Petrolina, IFSERTÃO-PE, 2016.

\begin{tabular}{|c|c|c|c|c|c|}
\hline \multicolumn{2}{|r|}{ Hybrids } & \multicolumn{2}{|c|}{ Irrigation system } & \multicolumn{2}{|c|}{ Ground cover } \\
\hline H1 & $39.54475 \mathrm{a}$ & S1 & $39.12037 \mathrm{a}$ & $\mathrm{C} 1$ & $40.27778 \mathrm{ab}$ \\
\hline $\mathrm{H} 2$ & $38.92747 \mathrm{a}$ & S2 & $39.35185 \mathrm{a}$ & $\mathrm{C} 2$ & $43.51852 \mathrm{a}$ \\
\hline & ---- & & ---- & C3 & $33.91204 \mathrm{~b}$ \\
\hline & 6.52959 & & 6.06544 & & 7.76151 \\
\hline
\end{tabular}

Means followed by the same letters in the columns do not differ from each other by the Tukey test at 5\% probability.

Table 2. Mean yield of commercial yield ( $\mathrm{kg} / \mathrm{ha}$ ) of melon submitted to two hybrids, two irrigation systems and three soil coverages. Petrolina, IFSERTÃO-PE, 2016.

\begin{tabular}{|c|c|c|c|c|c|}
\hline \multicolumn{2}{|r|}{ Hybrids } & \multicolumn{2}{|c|}{ Irrigation system } & \multicolumn{2}{|c|}{ Ground cover } \\
\hline $\mathrm{H} 1$ & $29.39815 \mathrm{a}$ & S1 & $28.74228 \mathrm{a}$ & $\mathrm{C} 1$ & $32.34954 \mathrm{a}$ \\
\hline \multirow[t]{2}{*}{$\mathrm{H} 2$} & $28.89660 \mathrm{a}$ & S2 & $29.55247 \mathrm{a}$ & $\mathrm{C} 2$ & $32.81250 \mathrm{a}$ \\
\hline & ---- & & ---- & $\mathrm{C} 3$ & $22.28009 \mathrm{~b}$ \\
\hline & 6.16988 & & 4.39739 & & 7.31337 \\
\hline
\end{tabular}

Means followed by the same letters in the columns do not differ from each other by the Tukey test at 5\% probability.

Table 3. Mean results for total melon fruits submitted to two hybrids, two irrigation systems and three soil coverages. Petrolina, IFSERTÃO-PE, 2016.

\begin{tabular}{|c|c|c|c|c|c|}
\hline \multicolumn{2}{|r|}{ Hybrids } & \multicolumn{2}{|c|}{ Irrigation system } & \multicolumn{2}{|c|}{ Ground cover } \\
\hline $\mathrm{H} 1$ & $8.47222 \mathrm{a}$ & S1 & $8.19445 \mathrm{a}$ & $\overline{\mathrm{C} 1}$ & $8.08333 \mathrm{a}$ \\
\hline $\mathrm{H} 2$ & $8.11111 \mathrm{a}$ & S2 & $8.38889 \mathrm{a}$ & $\mathrm{C} 2$ & $8.91667 \mathrm{a}$ \\
\hline & ---- & & -- & C3 & $7.87500 \mathrm{a}$ \\
\hline
\end{tabular}

Means followed by the same letters in the columns do not differ from each other by the Tukey test at 5\% probability.

\section{REFERENCIAS}

ALLEN, R. G.; PEREIRA, L. S.; RAES, D.; SMITH, M. Crop evapotranspiration: guidelines for computing crop water requirements. Rome: FAO, 1998, 297p. FAO. Irrigation and Drainage Paper, 56.

BATISTA, P. F.; PIRES, M. M. M. L.; SANTOS, J. S.; QUEIROZ, S. O. P.; ARAGÃO, C. A.; DANTAS, B. F. Produção e qualidade de frutos de melão submetidos a dois sistemas de irrigação. Horticultura Brasileira, 27:246-250. 2009. 
BRANDENBERGER, L.; WIENDENFELD, B. Physical characteristics of mulches and their impact on crop response and profitability in muskmelon production. Horttechnology, Alexandria, v. 7, p. 165-169, 1997.

GOMES, H. P. Engenharia de irrigação: hidráulica dos sistemas pressurizados, aspersão e gotejamento. 3.ed. Campina Grande: Ed. UFPB, 1999. 412 p.

LEMOS, L.M.C.; SANTOS, S.R.; LEMOS, J.P. Crescimento do meloeiro Cantaloupe sob manejo de irrigação por gotejamento em Janaúba, Minas Gerais. Rev. Ceres, Viçosa, v. 59, n.5, p. 614-623, 2012.

LIMA, E.M.C. Irrigação do meloeiro cultivado em ambiente protegido. Lavras: UFLA. Tese de doutorado em Recursos hídrico em sistemas agrícolas. Universidade Federal de Lavras. 139p. 2015.

MANTOVANI, E. C.; BERNARDO, S.; PALARETTI, L. F. Irrigação: princípios e métodos. 3 ed., atualizada e ampliada, Viçosa: Ed. UFV, 2009. 355p.

MEDEIROS, JF de et al. "Crescimento e produção do melão cultivado sob cobertura de solo e diferentes freqüências de irrigação. Revista Brasileira de Engenharia Agrícola e Ambiental 10.4 (2006): 792-797.

MONTEIRO, Rodrigo Otávio Câmara. Influência do gotejamento subterrâneo e do mulching plástico na cultura do melão em ambiente protegido. 2007. Tese de Doutorado. Universidade de São Paulo.

OLIVEIRA PTL. 2010. Aspectos fisiológicos e comportamentais de novilhos da raça Sindi, fistulados e não-fistulados, alimentados com dietas contendo teores crescentes de feno de ervasal no Semiárido pernambucano. Petrolina: Universidade Federal do Vale do São Francisco. 80p. (Dissertação mestrado).

SILVA, M.C.C.; Medeiros, J.F.; Negreiros, M. Z.; Sousa, V.F. Produtividade de frutos do meloeiro sob diferentes níveis de salinidade da água de irrigação, com e sem cobertura do solo. Horticultura Brasileira, Brasília, v.23, n.2, p. 202-205, 2005.

SAMPAIO, R.A. et al. Resposta do tomateiro à fertirrigação potássica e cobertura plástica do solo. Pesq. Agropecu. Bras ., Brasília, v. 34, p. 21-30, 1999.

SHMUELI, M. \& GOLDBERG, D. Riego por aspersión, por surcos y por Goteo dei Meián en una Zona Anda. Israel, Universidade Hebrea de Jerusalem, 1971. 5 p. 
C. E. F. Possidio et al.

VERMEIREN, G. A., JOBLING, G. A. Irrigação localizada. Campina Grande: UFPB, 1997, 184p. (Estudos FAO: Irrigação e Drenagem, 36 - Tradução de GHEYI, H. R., DAMASCENO, F. A. V., SILVA JUNIOR, L. G . A., MEDEIROS, J. F.).

ZAPATA, M. et al. El melon. Madrid: Mundi-Prensa, 1989. 